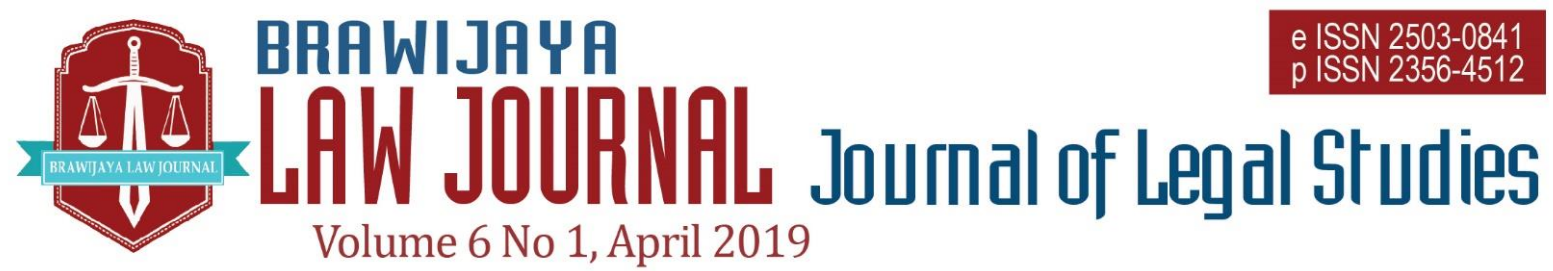

Nationally Accredited No. 30/E/KPT/2018 Dated 24th October 2018

This work is licensed under a Creative Commons Attribution-NonCommercial 4.0 International License

\title{
An Assessment of the 'Lawfulness' of Use of Force as Dispute Settlement Method
}

\author{
Md Mustakimur Rahman ${ }^{a}$, Mohsina Hossain Tushi ${ }^{b}$ \\ ${ }^{a}$ Faculty Member, Department of Law, Notre Dame University Bangladesh \\ Email:mrahman.ntu@ outlook.com \\ ${ }^{b}$ Assistant Judge, Kishorganj Judge Court, Kishorganj, Bangladesh \\ Email: htushi@gmail.com
}

Submitted : 2018-10-12 | Accepted : 2019-03-13

\begin{abstract}
Public international law has been developing and working with international humanitarian law \& international human rights law together. As it developes, international law is renovating its nature from softer to harder. Although it is a great achievement to see that international (criminal) law has the influence to deal with some particular international criminals, however, the world is still far beyond from its ambition. Sometimes states are behaving very unusual against other states and using force for various reasons. While using force against other states is prohibited under Article 2(4) of the UN Charter. Nevertheless, states can use force under Article 51 if it is necessary for self-defence and only if it is approved by the Security Council under Chapter VII of the UN Charter. However, it is a question of fact that how a state can use force(s) and how it will be legitimate under several international laws? Hague law prohibits the use of new weapons and engine in the war because it seems disproportionate and unnecessary while the UN Charter is silent about the method of using force. Hence, it seems not clear that how a 'force' would be measured and will pass the 'legality' test. The indicator, thus remain unclear and very subjective. This research uses normative legal research with statute approach and case study approach, especially analysing some practices of use of forces against various states; such as Iraq and Kosovo.
\end{abstract}

Keywords: dispute settlement; use of force; self-defence; international humanitarian law; international criminal law.

\section{INTRODUCTION}

Current development in International Law shows that the human rights factor affects every decision of States in conducting international relation. While the United Nations Charter (UN Charter) emphasizes on peacefull settlement in any disputes arose between States and other subject of
International Law, the use of force is also recognized as one of disputes settlement methods in international fora. However, such method is allowed only under special circumstances, which include self-defense, as envisages under Article 51 of the UN Charter and if it is approved by the Security Councel under Chapter VII of the UN 
Charter. Thus, Charter only says that states can use force for self-defence, but does not provide any particular way to use force. However, neither the Charter sets any category of weapons that can be used during armed conflict.

$$
\text { Jus in Bello (International }
$$
humanitarian law) and jus ad Bellum (laws of war) are two separate areas of law, but both branches of laws dealing with the use of force during armed conflict. ${ }^{1}$ In the case of jus ad bellum, the law regulates the right to use of force; such as: whether or not the reason for using force was legitimate and reasonable? On the other hand, jus in bello regulates the measure of force using in the war. Justifying the necessity and proportionality is very important for any war. In the case of any particular armed conflict, use of force may be allowed under jus ad bellum; however, that particular force could be unnecessary and disproportionate under jus in bello. Hence, the necessity to know the 'lawfulness' of any use of force is very significant.

This research seeks to analyse how a state can use force(s) and how it will be legitimate under international laws? Can it be used as a dispute settlement method?

\section{LEGAL MATERIALS AND METHODS}

Legal methodology used in this research is normative method, which analyses relevant legal instruments relating to the use of force under international laws. While the primary legal materials consist of all the legal framework related to the use of force as well as humanitarian and human

Keiichiro Okimoto, 'The Cumulative Requirements of Jus ad Bellum and Jus in Bello in the Context of Self-Defense' (2012) 11(1) Chinese Journal of International Law 2.

2 IHL and other legal regimes - jus ad bellum and jus in bello, International Committee of the Red Cross (29-10-2010), rights laws, secondary ones included the references, including books, journal articles as well as conference papers and other documents having correlation with the issues. The technique of analysis data used legal interpretation.

Legal materials used include Charter of the United Nations 1945, the Geneva Convention 1949, Rome Statute of the International Criminal Court 1998 as well as the Statute of International Court of Justice

\section{RESULT AND DISCUSSION}

\section{Distinction between Jus Ad Bellum and Jus In Bello in Relation to 'Use Of Force'}

Although jus is bello is a part of jus ad bellum, there is a clear distinction between them. This distinction is relatively new and became a debatable issue just after a decade of WWII. ${ }^{2}$ The theory of war is a theory of morality, but not law. This moral theory is a theory that separates the two doctrines. ${ }^{3}$ In case of the theory of war, all combatants have the same rights and liabilities. It does not matter whether they fight in any just or unjust war. ${ }^{4}$ In addition, a combatant is not guilty of participating in any war, rather he would be liable for not following the rules of the war. However, there is a close connection between ad bellum and in bello. For example, in reaction to an Israeli attack in the Gaza in December 2008 and in January 2009, a question had been asked that whether or not Israel's attacks were disproportionate. In return to this question, the US ambassador to the UN answered, "Israel has the right to defend itself against these rocket attacks and

\footnotetext{
<https://www.icrc.org/en/doc/war-and-law/ihlother-legal-regmies/jus-in-bello-jus-adbellum/overview-jus-ad-bellum-jus-in-bello.htm> 3 Jeff McMahon, 'Morality, Law, and the Relation Between Jus ad Bellum and Jus in Bello' (2006) 100 American Society of International Law 46
} 4 Ibid. 
we understand also that Israel needs to do all that it can to make sure that the impact of its exercise of right of self-defence against rockets is as minimal and no effect [sic] on the civilian population." 5 This statement shows that an attack may be justified but that must be proportionate and should not create any risk for the civilians. This is the linked between these two doctrines. Let us discuss these two doctrines considering the idea of modern international law.

Article 2(4) of the UN Charter prohibits states from using force against any state. However, the same Charter also states that the use of force could be legal under two different circumstances; they are: Article 51 (self-defence) and chapter VII (collective force). ${ }^{6}$ If any state uses force unlawfully, then International law allows the victim state to use force lawfully against the attacking state. This may be legally done under Article 51 (self-defence) or by a resolution ${ }^{7}$ approved by the Security Council under Chapter VII of the UN Charter. Thus, the Charter only says that the state can use force for self-defence, but nothing is written about the procedure of using force. Neither the Charter talks about any particular weapon that may be used in the armed conflict, although this issue was illustrated in the Nuclear Weapon Advisory Opinion (NWAO). ${ }^{8}$ In 1996, the International Court of Justice (ICJ) stated in the Advisory Opinion on the matter of Legality of the Threat or Use of Nuclear Weapons. ${ }^{9}$

5 Press Release, U.S. Mission to the U.N., Statement by Ambassador Zalmay Khalilzad, U.S. Permanent Representative, on the Situation in Gaza (Dec. 31, 2008), available at $<$ http://www.usunny.us/pressjreleases/20081231_ 381.html>

6 Bruno Simma, 'NATO, the UN and the Use of Force'(1999) 10 The European Journal of International Law 3

7 Sanction can be suspension of UN membership, military/paramilitary force enforcement etc.
However, it neither directly prohibits nor agrees to use any force including nuclear weapon. ${ }^{10}$ As a result, it remains unclear whether a state can use force as much as a state wants. While we are discussing the UN Charter that connects with the validity of the use of force, we must remember that the Charter has no control into the procedure of using of force. If any state wants to use any force, then they have to follow some procedure which must be proportionate and necessary. If any force is not proportionate and necessary to use, then that may create risk for the civilians. In general, humanitarian law covers this area.

The main focus of humanitarian law is to protect noncombatants during any armed conflict. ${ }^{11}$ This protection is given under Jus in Bello which is applicable to all noncombatants including the civilians of the perpetrating state. ${ }^{12}$ The fundamental commitment of the humanitarian law is the 'principle of human dignity' where all human being possesses an intrinsic worth which should be protected. ${ }^{13}$ In terms of codification, the IHL has two parts under International law and these are Geneva Law and Hague law. ${ }^{14}$ The two branches of laws play different roles in humanitarian intervention. Geneva law assists the victims during armed conflict and Hague law regulates the legality and methods of use of force. Under the Hague law, it is prohibited to use new weapon and engine in the war

8 Advisory Opinion of the International Court of Justice 1996

9 Ibid

10 Ibid

11 Keiichiro Okimoto, above n 1, 5

12 Ibid

13 Gerald L. Neuman, 'Humanitarian law and counterterrorist force'(2003) 14(2) European Journal of International Law Oxford University Press 2

14 Ibid

40 | Rahman, Tushi - An Assessment of The 'Lawfulness' of Use Of Force As Dispute Settlement Method 
because of disproportion and unnecessity, ${ }^{15}$ while in the UN Charter, there is no restriction or limitation of using any weapon which was confirmed in the Advisory opinion $1996 .{ }^{16}$ Hence, it can be argued that there are some contradictions in assessing the "lawfulness" of the use of force in the eye of Humanitarian law and International law. While the principles of lex speciali derogat legi generali could be applied and thus the Hague Law prevails, however, the Hague Laws only applied to those who ratifies the Laws. It is thus submitted that the agreed universal provisions are needed to achieve legal certainty.

\section{Humanitarian Intervention And the Legitimacy of Use of Force}

All the signatory states of International Humanitarian Laws (IHL) are bound to follow the Common Article 3 of the Geneva Conventions $1954^{17}$, Hague Convention, and the Convention on Certain Conventional Weapon (CCW) etc. These laws mainly

15 Ibid

16 Advisory Opinion of the International Court of Justice 1996

17 ARTICLE 3 is common to the four Geneva Conventions of 1949

"In the case of armed conflict not of an international character occurring in the territory of one of the High Contracting Parties, each Party to the conflict shall be bound to apply, as a minimum, the following provisions:

(1) Persons taking no active part in the hostilities, including members of armed forces who have laid down their arms and those placed ' hors de combat ' by sickness, wounds, detention, or any other cause, shall in all circumstances be treated humanely, without any adverse distinction founded on race, colour, religion or faith, sex, birth or wealth, or any other similar criteria.

To this end, the following acts are and shall remain prohibited at any time and in any place whatsoever with respect to the abovementioned persons:
(a) violence to life and person, in particular murder of all kinds, mutilation, cruel treatment and torture;

(b) taking of hostages; cover the war rules during armed conflict, whether it is international or noninternational. In addition to this, these laws protect the civilians too. Considering the rules of war, it is clear that IHL covers war crime and crimes against humanity, but it does not cover genocide as genocide is possible during peacetime which is beyond the jurisdiction of IHL. Moving back to the point of war crime and crimes against humanity, any war crime may constitute a violation of IHL and therefore, an individual may be responsible for his criminal activity under IHL. ${ }^{18}$ The first witness of recognizing the IHL principle can be seen in the Hostage case of the US Military Tribunal at Nuremberg. ${ }^{19}$ In this case, the Tribunal stated that the legality of the use of force had no validity upon the application of the law of occupation. 20 Usually, humanitarian intervention arises from war or use of force. According to Kelsen, "war is permitted

(c) outrages upon personal dignity, in particular humiliating and degrading treatment;

(d) the passing of sentences and the carrying out of executions without previous judgment pronounced by a regularly constituted court, affording all the judicial guarantees which are recognized as indispensable by civilized peoples.

(2) The wounded and sick shall be collected and cared for. An impartial humanitarian body, such as the International Committee of the Red Cross, may offer its services to the Parties to the conflict. The Parties to the conflict should further endeavour to bring into force, by means of special agreements, all or part of the other provisions of the present Convention.

The application of the preceding provisions shall not affect the legal status of the Parties to the conflict."

18 Sandesh Sivakumaran,, 'Re-envisaging the international law of internal armed conflict'(2011) 12(1) European Journal of International Law, Oxford University Press 10.

19 Keiichiro Okimoto, above n 1, 7.

20 Hostage Case, US Military Tribunal, Nuremberg, Judgment of 19 February 1948, p 1305. 
against illegal act"; ${ }^{21}$ however, the war must be lawful in response to any illegal action. Moreover, at the end of the $20^{\text {th }}$ century, the doctrine has changed a lot and developed in favour of a legal measure of "humanitarian intervention". 22

The first concentration of humanitarian intervention war was NATO's intervention in Kosovo ${ }^{23}$. This bombing campaign has begun on $24^{\text {th }}$ March 1999 and continued 78 days which was known as Operation Allied Force. Although the main purpose of this operation was to protect the civilian, a massive number of civilians died because of NATO's bombing. ${ }^{24}$ The question was whether or not the intervention was "lawful" under the modern humanitarian law? The UN Charter has not mentioned clearly anything about humanitarian intervention, but the Charter says not to use force against states ${ }^{25}$ unless it is necessary for self-defence ${ }^{26}$ or it is approved by the Security Council under the Chapter VII of the Charter. Regarding NATO's intervention, Yugoslavia claimed that NATO's bombing caused numerous civilian casualties. ${ }^{27}$ Hence, attacking Kosovo by NATO was in question because the outbreak was not authorized by the Security Council neither it was for selfdefence. However, some international lawyers have argued that the intervention was lawful under the customary international law and they think that the idea of humanitarian intervention existed in the past already. ${ }^{28}$ While we consider NATO's action against

21 Yoram Dinstein, 'War Aggression and Selfdefence' (2007) 18(4) European Human Rights Law Review 67

22 Ibid, 71

23 Gabriel Vockel, 'Humanitarian intervention in cases of overwhelming humanitarian necessity'(2005) 10(1) Coventry Law Journal 1

24 Kenneth Roth, 'Was the Iraq War a Humanitarian Intervention?' (2006) 5(2) Journal of Military Ethics 11
Kosovo, it was a question to ask whether the intervention was proportionate or not.

Furthermore, the initial reason behind NATO's attack was against war crime, genocide, and crime against humanity in Kosovo which was recognized under international law and humanitarian law. These crimes were a serious violation of the humanitarian law, international law and international criminal law. While we are discussing the fact of Kosovo, we must not forget that International Criminal Tribunal for the former Yugoslavia (ICTY) is dealing with this matter. This was the first time where an international criminal tribunal has been established by the UN in May 1993. ${ }^{29}$ This tribunal has brought the issue of individual criminal responsibility for unlawful humanitarian intervention in Kosovo. ${ }^{30}$

Coming back to the point of humanitarian intervention, undoubtedly, it may be necessary for some situations to stop 'mass killing', in fact, it could be legal and justified. Although the validity of any external intervention varies from situation to situation. For example, intervention in Iraq was in question and several academics and international lawyers have criticised the US's intervention against Iraq. The forces used against Iraq was neither for self-defence nor was it approved by the Security Council. Regarding intervention in Iraq, Ken Roth described in his article that forces used in Iraq could be characterized as a humanitarian intervention only if it meets five important factors. ${ }^{31}$ These factors are: "use of force

25 Article 2(4) of the UN Charter 1945

26 Article 51 of the UN Charter 1945

27 Kenneth Roth, above n 26, 11.

28 Gabriel Vockel, above n 25, 3.

29 United Nations, International Criminal Tribunal for former Yugoslavia <http://www.icty.org/en/about > (accessed November 20, 2018).

30 Ibid

31 Kenneth Roth, above n 26, 4. 
must be last option to prevent killing, the intervention for humanitarian purpose, measure of force must not violate human rights and humanitarian law, use of force has to be better for civilian rather than making more harm and it would be far fair if it can be endorsed by the Security Council". ${ }^{32}$ Before analysing these factors, it has to be clear that whether or not any force was required against Iraq in 2003. As mentioned above that humanitarian intervention may be required in a situation where the level of killing is high which can be considered as a 'mass killing'. ${ }^{33}$ While we analyse the history and find that Iraq used a chemical weapon in 1988 against Iranian soldiers and slaughtered around 100,000 Kurds, ${ }^{34}$ nevertheless the level of killing in 2003 was not mass. Therefore, humanitarian intervention could have happened in 1988 instead of 2003. Moreover, the intervention could be justified as 'lawful' if the force was used to halt future threat, but evidence shows that Iraq had no plan to do something like they have done in $1988 .{ }^{35}$ Moving on to those five factors mentioned by Roth, we know that Iraq intervention was not sanctioned by the Security Council and also the forces used against Iraq caused a lot of casualties including deaths and wounded of civilians. Undoubtedly this incident was a violation and disrespect of the humanitarian law. Based on the analysis of the Iraq incident, it remains unsolved and we find no strong grounds to justify the validity of forces used against Iraq.

Ibid, 5.

33 Ibid, 6.

34 Ibid.

35 Ibid.

36 Gerald L. Neuman, above n 15, 6.

37 For an exhaustive list of international instruments on terrorism, see the Internet site UN action against terrorism, http://www.un.org/terrorism

38 Convention on Offences and Certain Other Acts Committed on Board Aircraft, 1963; Convention for the Suppression of Unlawful Seizure of

\section{Terrorism and International}

\section{Humanitarian Law}

After the 9/11 incidents, states have seriously taken the issues of terrorism and territorial security seriously. Therefore, it is imperative to understand the relationship between IHL and terrorism. In general, when a state attacks a terrorist group without any prior permission from the host nation, then it may constitute an international armed conflict. ${ }^{36}$ Before going into deep, we must know the status of 'terrorist' and 'terrorism' under IHL. Coming to the horizon of IHL, it is to clarify that IHL only applies to armed conflicts. Thus, only those terrorist activities will be covered under IHL if they are committed within the agenda of armed conflict. In addition, it is to remember that terrorism committed in a situation of any internal violence or during peacetime, then those activities will not be covered by IHL. ${ }^{37}$

As mentioned above that states have taken the issue of terrorism seriously, it would not be a surprise to articulate that, at present, there is no universal treaty that strictly prohibits terrorism and applied in all conditions. Although, an attempt had been taken to establish a treaty in 1937 which was the Convention for the Prevention and Punishment of Terrorism, unfortunately, that Convention has never been entered into force. Nonetheless, the United Nations has adopted a few treaties dealing with terrorism. ${ }^{38}$ In case of IHL, the four Geneva Conventions and two Additional Protocols are mainly

\footnotetext{
Aircraft, 1970; Convention for the Suppression of Unlawful Acts against the Safety of Civil Aviation, 1971; Convention on the Prevention and Punishment of Crimes against Internationally Protected Persons, including Diplomatic Agents, 1973; Convention against the Taking of Hostages, 1979; Convention for the Suppression of Unlawful Acts against the Safety of Maritime Navigation, 1988; International Convention for the Suppression of Terrorist Bombings, 1997;
} 
designed to protect the war victims. However, none of the above-mentioned Conventions has established a definition of 'terrorism' or 'terrorist act'. Thus, under IHL, there is no clear status of a 'terrorist' in connection to either international or non-international armed conflicts, although, in general, terrorist acts are crimes under domestic law and also some activities may qualify as war crimes or as crimes against humanity. ${ }^{39}$ Nevertheless, the Geneva Conventions do not support any terrorism. Article 33 of the Fourth Geneva Convention states that "No protected person may be punished for an offence he or she has not personally committed. Collective penalties and likewise all measures of intimidation or of terrorism are prohibited." This is the only provision where the term 'terrorism' has been used. Although the term 'terrorism' used in the Geneva Convention has a narrow meaning in compare to modern-day language. For example, the activities like wilful killing, torture or inhuman treatment will not form any terrorism, rather they are grave breaches of the Convention; such as war crime. ${ }^{40}$

Of course, they have to fulfil the threshold and once the threshold of armed conflict has been reached, it may be argued that acts of violence against civilians or civilian objects as "terrorist" because such acts already constitute war crimes under IHL. ${ }^{41}$ Under the Geneva Conventions, the act of terrorism may occur in international

International Convention for the Suppression of the Financing of Terrorism, 1999

39 International humanitarian law and the challenges of contemporary armed conflicts, Document prepared by the International Committee of the Red Cross for the 30th International Conference of the Red Cross and Red Crescent, Geneva, Switzerland, 26-30 November 2007; https://www.icrc.org/en/doc/assets/files/other/irrc -867-ihl-challenges.pdf

40 Fourth Convention, Article 147.

${ }^{41}$ Above $\mathrm{n} 41$ armed conflict and also a non-international armed conflict. For example: the war occurred between the US-led coalition and the Taliban regime in Afghanistan is a case of an international armed conflict and the war between the Afghan government and terrorist groups like Taliban and Al- Qaeda if a form of non-international armed conflict. ${ }^{42}$

In both cases, international and noninternational, IHL prohibits the most common type of terrorist activities; such as attacks against non-combatants, 43 indiscriminate attacks, ${ }^{44}$ acts or threats whose main aim is to spread terror among the civilian population ${ }^{45}$ and acts of "terrorism" aimed against civilians in the power of the enemy. ${ }^{46}$ As stated above that if the activities are considered to be a war crime then that must be universally prosecuted. ${ }^{47}$ However, all acts are not prohibited by IHL and this may be an attack against military objectives.

Coming to the fact of status of a terrorist, if anybody is detained in an international armed conflict then IHL will fully apply to him and in case of any noninternational armed conflict, the deprivation of liberty is governed by Common Article 3, other applicable treaties, customary international law, and other bodies of law such as human rights law and domestic law will apply.

Nonetheless, no act of terrorism is compatible with any provision of international humanitarian law and it is a core

42 Ibid

43 Protocol I, Article 51(2); P II, Art. 13(2)

44 Protocol I, Article 51(4) and (5)

45 Protocol I, Article 51(2); P II, Art. 13(2)

46 Geneva Convention IV, Art. 33(1). In noninternational armed conflicts Art. 4(2) of Protocol II extends this protection to all individuals who do not or no longer directly participate in the hostilities.

47 Geneva Convention IV, Art. 147; P I, Art. 85(3)(a); ICC Statute, Art. 8(2)(e)(i)] 
duty of any state party to those treaties to find the solution. In addition, states have a legitimate interest in stopping criminal behaviour as well as to protect their own citizens. ${ }^{48}$ Besides, any third states may respond to grave breach or prevent further violation which is not prohibited by the Geneva Conventions, although this may happen only if the state does not take any appropriate action to stop terrorism. While IHL grants permission to use of force to stop terrorism during armed conflict, it creates a conflict under the UN Charter as the Charter doesn't allow any state to use force against another state without the approval of the Security Council or for self-defence. ${ }^{49}$

\section{Enduring Armed Conflict and}

\section{Humanitarian Law}

At present, we are having two armed conflicts in Syria and Palestine. In Syria, civilians are facing several humanitarian difficulties and death due to internal conflicts between the government and others. Although the Security Council tried to take a step against this situation; however, due to negative votes from China and Russia, the Security Council has failed to adopt any resolution. ${ }^{50}$ Consequently, no external force has been used against Syria to prevent this humanitarian crisis. As a result, civilians are suffering and the refugee crisis. Humanitarian laws are being violated and so many refugees are fleeing abroad, but still,

48 Article 1 common to the four 1949 Geneva Conventions recalls this basic truth with the following words: "The High Contracting Parties undertake to respect and to ensure respect for the present Convention in all circumstances".

49 Hans-Peter Gasser, 'Ensuring respect for the Geneva Conventions and Protocols: The role of third States and the United Nations', Hazel Fox and Michael A. Meyer (eds), Effecting Compliance, The British Institute of International and Comparative Law, London, 1993, pp. 15-49, esp. p. 27 we do not notice adequate international response to minimize this issue. A general question can be raised that if NATO is so much concern about humanitarian intervention then why the NATO is not captivating any step against Syrian issue? Why the NATO was so concerned about Kosovo? We all know about the situation of Palestine. The legal consequence of the Palestinian wall was a big question for the international community. In 2004, the ICJ has given an advisory opinion. The court articulates in its opinion that "The construction of the wall being built by Israel, the occupying Power, in the Occupied Palestinian Territory, including in and around East Jerusalem, and its associated regime, are contrary to international law". 51 But we do not see any humanitarian action to stop the crisis of Palestine.

\section{Conflict Between Humanitarian Law and Public International Law}

International law utters that heads of the states are immune from any criminal prosecution. This idea came from the concept of "state sovereignty" where heads of the states are the representatives of the states; therefore, the status of the states and status of the heads of states are literally similar. However, the $21^{\text {st }}$ century's laws are arguing to make a distinction between state and heads of the states. Where there is a legal gap between state and heads of the state. Any

50 Security Council Fails to Adopt Draft Resolution on Syria That Would Have Threatened Sanctions, Due to Negative Votes of China, Russian Federation, $19^{\text {th }}$ July 2012; see the official website: https://www.un.org/News/Press/docs/2012/sc107 14.doc.htm (accessed July 15, 2018)

51 ICJ advisory opinion 2004; see: http://www.icjcij.org/docket/index.php?pr=71\&p $1=3 \& \mathrm{p} 2=1 \&$ case $=131 \& \mathrm{p} 3=6$ (accessed July 15 , 2018) 
state itself cannot be liable for any criminal activities, but heads of the states may be responsible for criminal activities. Under this structure, any individual will be responsible for international crimes. Although not for all crime, some particular crimes illustrated in the Rome Statute. Those core international crimes are genocide, war crime, crimes against humanity and aggression. Violation of the Rome Statute may be also a violation of the humanitarian law. Under the universal jurisdiction, any state can take action against an international criminal. On the other hand, under international law, states are equally sovereign; therefore, if any state takes action against another state or heads of the states then that will be a violation of the principle of "state sovereignty". But the aims of $21^{\text {st }}$ century's international laws for international human rights are the protection of civilians and international peace. Hence, to justify the principle of "heads of state immunity" against any humanitarian law should be more scrutinized for the purpose of protection of civilians rather than the protection of heads/former heads of the state. For example, former President Pinochet was arrested under universal jurisdiction in London, UK for his criminal activities. ${ }^{52}$ The House of Lord denied immunity for Pinochet because of his criminal responsibilities including torture. ${ }^{53}$ His arrest was debatable under international law because it was a violation of "heads of the state immunity" principle; nevertheless, on the other hand, the new approach of jus cogens is the highest norm of law. Any

52 Naomi Roht Arriaza, 'The Pinochet Precedent and Universal Jurisdiction' (2001) 35(2) New England Review 311-319.

53 Ibid, 2.

54 Louse Philippe Rouillard, "the Caroline Case: Anticipatory Self-Defence in Contemporary International Law," 1, no. 2 (2004): 104-120.

55 Under Article 16 of the Rome Statute, "no investigation or prosecution may be commenced or proceeded with under this Statute for a period of violation of jus cogens should be prosecuted. Pinochet has violated the concept of jus cogens and he was arrested for that. The conflict of international law and humanitarian law was very critical; nevertheless, humanitarian law and human rights have prevailed here rather than the customary principle of "heads of state immunity".

\section{Limitation of Humanitarian Law and Lawful Use of force}

The perception of 'self-defence' has come from the Caroline case where Britain attacked some Canadian rebels in the United States. ${ }^{54}$ Using force against a nation as a defence is permitted under treaty law. In addition, under modern international law, using force is also permitted under Chapter VII of the UN Charter, but the point is whether the force permitted by Chapter VII would be under the legality test? In fact, there is no precise legal provision that may justify the legality of any force that has been authorised by the Security Council. For example, if the civilians face serious destruction and humanitarian crisis due to a collective force authorised by the SC, would the authority be liable for that [illegitimate] force? Although military commanders and superiors are responsible for their activities under Article 28 of the Rome Statute, it is a matter of question that whether the Prosecutor of the ICC would be able to exercise the jurisdiction over a crime authorised by the Security Council. ${ }^{55}$ The

12 months after the Security Council, in a resolution adopted under Chapter VII of the Charter of the United Nations, has requested the Court to that effect; that request may be renewed by the Council under the same conditions". Therefore, SC may defer any investigation. Furthermore, SC may refer any matter to the ICC under Article 13 of the Statute. However, it is to articulate that whether the SC would ever refer any 
concept of humanitarian intervention is relatively longstanding and part of the customary international law. Thus, any state can take action to protect civilians of another state. However, what will happen if any state takes the wrong action willingly or unwillingly and makes the situation even more vulnerable? NATO's bombing in Kosovo could be a good example where many civilians have died due to NATO's force, but then there was no question regarding the legitimacy of that particular force due to the authorisation of the SC. This is, of course, a kind of limitation of the international humanitarian law. In addition, humanitarian intervention is not possible during peacetime which may necessary in some situations. For example, the recent incident of Myanmar seeks international attention. Millions of Rohingyas have been persecuted which is may constitute crimes against humanity, but it was not a situation of any armed conflict and therefore, IHL would not apply.

\section{CONCLUSION AND SUGGESTION}

Under the UN Charter there is an obligatoir method in international disputes settlement both during armed conflict and during peace time, that is not exercising the use of force. Such obligation, however, can be breach under two circumstances that is for self-defense and as long as it is approved by the Security Council. Furthermore, while the use of ofrce can be used as a dispute settlement method, however, the analyses of relevant legal instruments show inconsistency between one legal instrument to another regarding the lawfulness of the use of force.
It is submiteed that the "lawfulness" of the use of force remains unclear and very subjective and thus resulted to a legal uncertainty. Prosecuting an individual for the international crime was not so common even before 100 years back. However, we are the witnesses of the greatest conjunction of the International Criminal Court (ICC) who has the power to prosecute the individual international criminal. We have also seen the International Criminal Tribunal for the former Yugoslavia (ITCY) \& International Criminal Tribunal for Rwanda (ICTR). The future leaders will understand the power of the ICC and consequences for violating humanitarian laws. States are being powerful through modern technologies and making weapons for upcoming wars. Nonetheless, states are also being aware of them. They know the consequences of misusing the force against any state. International laws are being stronger day by day; henceforth, abuse of them would not be good for any suspected criminal.

\section{REFERENCES}

\section{Journals Articles}

Arriaza, Naomi Roht, 'The Pinochet Precedent and Universal Jurisdiction' (2001) 35(2) New England Review.

Dinstein, Yoram, 'War Aggression and Selfdefence' (2007) European Human Rights Law Review.

Jeff McMahon, 'Morality, Law, and the Relation between Jus ad Bellum and Jus in Bello' (2006) 100, American Society of International Law.

Hans-Peter Gasser, 'Ensuring respect for the Geneva Conventions and Protocols: The role of third States and the United

matter to the ICC which was permitted by themselves 
Nations', Hazel Fox and Michael A. Meyer (eds), Effecting Compliance,(1993) The British Institute of International and Comparative Law, London.

Louse Philippe Rouillard, 'the Caroline Case: Anticipatory Self-Defence in Contemporary International Law,' 12 (2004): 104-120.

Neuman, Gerald L., 'Humanitarian law and counterterrorist force' (2003) 14(2) European Journal of International Law Oxford University Press.

Okimoto, Keiichiro, 'The Cumulative Requirements of Jus ad Bellum and Jus in Bello in the Context of Self-Defense' (2012) 11(1) Chinese journal of International Law.

Roth, Kenneth, 'Was the Iraq War a Humanitarian Intervention?' (2006) 5(2) Journal of Military Ethics.

Rouillard, Louse Philippe, 'The Caroline Case: Anticipatory Self-Defence in Contemporary International Law' (2004) 1 (2) Miskolc Journal of International Law 104-120.

Simma, Bruno, 'NATO, the UN and the Use of Force'(1999) 10 The European Journal of International Law.

Sivakumaran, Sandesh, 'Re-envisaging the international law of internal armed conflict' (2011) 12(1) European Journal of International Law, Oxford University Press.

Vockel, Gabriel, 'Humanitarian intervention in cases of overwhelming humanitarian necessity'(2005) 10(1) Coventry Law Journal.

\section{Statute And Case Law}

Advisory Opinion of the International Court of Justice 1996.

Charter of the United Nations 1945.
Common Article 3 of the Geneva Convention 1949.

Rome Statute of the International Criminal Court 1998.

US Military Tribunal in Nuremberg, List and Others (Hostage Case), Judgment, 8 Law Reports of Trials of War Criminals (1949).

\section{Internet Resources}

International Court of Justice, Advisory Opinion (2004) <https://www.icjcij.org/files/case-related/131/13120040709-ADV-01-00-EN.pdf>

International humanitarian law and the challenges of contemporary armed conflicts, Document prepared by the International Committee of the Red Cross for the $30^{\text {th }}$ International Conference of the Red Cross and Red Crescent, Geneva, Switzerland, 26-30 November 2007; $<$ https://www.icrc.org/en/doc/assets/fil es/other/irrc-867-ihl-challenges.pdf>

IHL and other legal regimes - jus ad bellum and jus in bello, 29-10-2010, International Committee of the Red Cross; see: https://www.icrc.org/en/doc/war-andlaw/ihl-other-legal-regmies/jus-inbello-jus-ad-bellum/overview-jus-adbellum-jus-in-bello.htm

United Nations Mechanism for International Criminal Tribunals Legacy, International Criminal Tribunal for Rwanda <http://www.unictr.org/AboutICTR/G eneralInformation/tabid/101/Default.a $\operatorname{spx}>$

United Nations, International Criminal Tribunal for former Yugoslavia <http://www.icty.org/en/about >

United Nations, Security Council Fails to Adopt Draft Resolution on Syria That 
Would Have Threatened Sanctions, Due to Negative Votes of China, Russian Federation (19 July 2012)
<https://www.un.org/News/Press/docs /2012/sc10714.doc.htm> 